\title{
ILCEA
}

Revue de l'Institut des langues et cultures

d'Europe, Amérique, Afrique, Asie et Australie

$40 \mid 2020$

English for Specific Purposes (ESP) and the Underlying Dynamics of Power, Empowerment and Disempowerment

\section{Narrow-Angled ESP as a Proponent of Neoliberal Capitalism and Its Inherent Empowering/ Disempowering Dichotomy}

L'anglais de spécialité comme vecteur du capitalisme néolibéral et l'inhérente dichotomie de la prise et la perte du pouvoir

Nadežda Stojković

\section{(2) OpenEdition}

\section{Electronic version}

URL: http://journals.openedition.org/ilcea/10549

DOI: 10.4000/ilcea.10549

ISSN: 2101-0609

\section{Publisher}

UGA Éditions/Université Grenoble Alpes

\section{Printed version}

ISBN: 978-2-37747-204-8

ISSN: $1639-6073$

\section{Electronic reference}

Nadežda Stojković, « Narrow-Angled ESP as a Proponent of Neoliberal Capitalism and Its Inherent Empowering/Disempowering Dichotomy », ILCEA [Online], 40 | 2020, Online since 04 June 2020, connection on 08 September 2020. URL : http://journals.openedition.org/ilcea/10549; DOI : https:// doi.org/10.4000/ilcea.10549

This text was automatically generated on 8 September 2020.

(C) ILCEA 


\section{Narrow-Angled ESP as a Proponent of Neoliberal Capitalism and Its Inherent Empowering/ Disempowering Dichotomy}

L'anglais de spécialité comme vecteur du capitalisme néolibéral et l'inhérente dichotomie de la prise et la perte du pouvoir

Nadežda Stojković

\section{Overview of LSP instruction and objectives}

1 The approach to language teaching that has gained ground in academia and various other formats of life-long learning, has, for the last four decades, been referred to as teaching Languages for Specific Purposes (LSP). The traditional characteristics of LSP instruction, course preparation and performance, are today well established and widely known, the main characteristics of LSP and its departure from general language teaching being contained in the denotative adjective 'specific'. The primary characteristic of LSP language courses may, consequently, be defined by the fact that they are not predesigned on a massive scale, but prepared for each particular course. This overarching characteristic subsumes all the others that stem from it since every aspect of a course needs to be designed by analyzing and taking into account all the elements that make it 'special'. As a result LSP courses are designed for a particular group of students on the basis of the previously investigated linguistic abilities they need to acquire relating to learners' current or prospective professional or scientific engagements, in an identified setting. The linguistic instruction and teaching and learning material is subsequently strictly designed in accordance with the genre and discourse practices of the domain's professional setting. 
2 In view of this, LSP is a type of language instruction that places heavy demands on designing and implementing the course, much more so than other forms of language teaching. Since LSP instructors must cater to every nuance of the target professional linguistic community's features, and also accommodate their teaching approach to the learners' profiles, the process needs to be reviewed in all its phases for each new course and group of students to ensure the peculiarities of the teaching/learning context are taken into consideration and the instruction modeled to accommodate both course design and learner requirements. This elaborate preparation of teaching is done with the sole objective of preparing learners for rapid and successful linguistic immersion into the desired professional community of practice.

However, certain LSP courses are designed with the broader view of meeting present and also future needs, in that the (future) professionals should be equipped to be able, not only to fully develop and express their expertise, but also to integrate future developments in the specialized language into their work, the objective being that LSP instruction should allow learners not only to obtain and keep jobs but also to advance in their careers.

When ESP first rose to prominence after World War II, it was perceived as a novel approach based on a more scientific and efficient basis than previous ones (Starfield, 2012), and therefore contributing to economic progress and development. This tenet largely rested on needs analysis, one of the defining pillars of ESP/LSP, which meant that it was essentially founded on identifying the linguistic norms and requirements of the professional setting. This, in turn, required an unprecedented degree of precision in achieving teaching goals, with care to avoid dissipating time and resources on language content not directly related to the designated environment, which explains why it has been referred to as "needs-based, pragmatic, cost-effective and functional" (Belcher, 2006: 134). In this, LSP teaching practices may be defined as being clearly market-driven, focusing on either preparing learners for a successful entry into professional communities or, if taught in any form of life-long learning, inservice training, or refresher courses, as a means of retaining their current jobs and enhancing their competitiveness.

5 This type of language instruction is unarguably a meaningful form of foreign language instruction among the adult, working population of learners, as it reflects "definable characteristics of the globalized nature of the given professional and scientific research strands, crucial linguistic abilities typical of a certain professional environment and sets of standardized academic skills" (Stojković, 2019). However, when discussing LSP in this light, it is relevant to question its limits with regard to the extent to which it empowers learners to express themselves out of the bounds of the restricted occupational field. To avoid reducing learners to being mechanistic performers, a certain degree of general proficiency should be targeted so as to enable learners to express themselves, their individuality, and their personal authenticity.

\section{Restrictive LSP vs General English}

Since LSP, as a reflection of professional domain language features, has a restricted focus, our claim here is that it is also a 'restrictive' language since this approach essentially implies a syllabus based exclusively on elements related to the professional setting, most notably, prominent rhetorical, syntactical structures, relevant 
grammatical and morphological units, writing models, and the like. Both approach and syllabus are based on ever-increasing responsiveness to the linguistic complexities of the domain institutions, simulating target professional linguistic situations. It is, thus, a highly situated view of literacy, reflecting the constraints of a given social context and the language used in it, the aim of the syllabus design being to find ways learners can gain control of them-an idea already affirmed by Hutchinson and Waters, when they affirmed that "[s]ociety sets the target (in the case of ESP, performance in the target situation) and the individuals must do their best to get as close to that target as possible" (1987: 72).

7 ESP is, consequently, in sharp contrast to the general language teaching from which it sprang. Topics and language characteristics other than those identified for the targeted professional and social setting are excluded from the syllabus, being perceived as unnecessary distraction and improper use of precious course time. As such, it limits learners' opportunities to develop broader language skills. In a non-ESP approach, varied topics, and simulation of situations encountered in everyday life, for example, are used to expand the learners' linguistic skills, thus enabling them to function adequately in diverse environments, in both reception and productive modes. Contrary to an LSP approach, the English for General Purposes (EGP) approach quite clearly focuses on empowering students to adapt linguistically to a number of complex social contexts which may be unpredictable and with multiple meanings.

\section{Pragmatism: a defining but questionable characteristic of LSP}

8 In the literature, LSP is often referred to as a pragmatic approach to language teaching since it primarily focuses on language use in context. LSP teaching is not concerned with presenting learners with abstract linguistic rules, but with applying a communicative approach to enable students to integrate into the desired community of practice by being able to reproduce its genres and discourses. Cleo H. Cherryholmes, one of the leading theoreticians of pragmatism, defines pragmatism as a discourse or practice that attempts to bridge where we are with where we want to end up (1999). He criticizes this focus on practical results and brings to the fore the issues of power which underlie this trend in education. The broader social issues of power relations have been largely ignored in over fifty years of ESP/LSP history (Swales, 1985), mostly because this practice of language teaching has, from its beginnings, been presented as 'neutral', focused on professional discourse and not on any reflection upon it. Pennycook argued this was a view of spreading and teaching English as something "natural, neutral and beneficial" (1994: 168). This discourse of neutrality has been promoted in theory as teaching a language that the learner benefits from as it represents an investment into their betterment. That this belief is identifiable in most aspects of LSP courses can be exemplified by the unquestioned assumptions regarding sources of material design (McDonough, 1986).

9 Recent decades, however, have witnessed a rise in voicing ideological and power issues in LSP which contest its 'neutral' pragmatism. Lyotard, for example, claims that "the games of scientific language become the games of the rich, in which whoever is the weatlhiest has the best chance of being right. An equation between wealth, efficiency, and truth is established" (1984: 45). Phillipson (1992), in turn, views the history of the 
spread of the English language as designed, organized, and heavily supported by governments and their foundations, as well as by businesses, which promote English language teaching through such establishment institutions as conferences, academic exchanges, publications, etc. In so doing, they ensure that language serves to align even further global markets and labor forces according to their economic interests.

With regard to English for Academic Purposes, in the early 1990s, Benesch had already criticized LSP pragmatism that seeks to fulfill target expectations without questioning the social inequalities that these might perpetuate (Benesch, 1993). In her later work, she goes even further to state explicitly that large scale ESP teaching and publishing projects are not driven by ideals of progress and global communication, but by the narrow interests of British neocolonialism and American capitalism and imperialism (Benesch, 2001). Such language programmes are also seen as having contributed to establishing English as a professional Lingua Franca, giving rise to subsequent issues of endangering other languages. Though Widdowson (2003) maintains a positive outlook and claims it is ESP that is the true bridge language of today, other linguists have perceived the phenomenon less positively: Phillipson (1992) refers to it as "linguistic neocolonialism", Master evokes "a subtle aspect of linguistic dominance" (1998: 720), while Crystal (1997) qualifies the sheer power of English as a professional lingua franca as "linguicide" with regard to other languages.

11 If the goals of this approach to LSP are to prepare students to enter and prosper in their chosen communities of practice, the implication is that those who are not exposed to this type of language instruction are left out of those communities, and so deprived of the opportunity to present and disseminate their talent, ideas and professional knowledge. This results in a situation which exemplifies one of the characteristics of present day neoliberal capitalism, by which certain categories remain or become underprivileged. Pennycook $(1994,1997,2001)$ and Phillipson (1992) claim that in this way the English language assumes an important role in producing, but equally relevantly, in reproducing unequal access to the resources of a professional career, both material and symbolic. This may be linked to matters of individual competitiveness, or alliances among particular professional and business groups, where mastery of professional discourse functions as a 'gatekeeper' to maintaining economic and political elites (Phillipson, 1992). In line with this argument, Morgan and Ramanathan (2005: 155) claim that such "politics of access" to disciplinary discourses serves to preserve and propagate vested power not only through texts in language instruction, but also in how "text users", i.e. the learners, are situated institutionally and socially.

One of the most sinister warnings of where such unreflecting language instruction may lead to can be seen in Lyotard's Postmodern Condition: A Report on Knowledge (1984) in which he elaborates on how the efficiency output of higher education (HE), or "performativity"-a term introduced by sociologist Stephen Ball (2003) to describe how individual practitioners are required to organize themselves in response to targets, indicators and evaluations-has become the overarching criterion of relevance of instruction. The goal of HE thus becomes to prepare students for optimal performativity within the social system, and as such creates and teaches skills-LSP among others-that are indispensable for the functioning and continuation of that system. In so doing, education conforms to the performance of neoliberal capitalism, ensuring not just successful participation in the world market economy, but also the 
continuation of the global culture of "performativity". Stronach and MacLure (1997) related "performativity" to the predominant trends in educational research as evidenced in the requirements for immediate instrumental relevance and contribution to the efficiency of the social system, much in the tradition of Lyotard (1984) whose insight into educational tendencies was that they were being redefined from pursuit of knowledge towards knowledge transmission for the sake of efficiency and skills as set out by social institutions (Lyotard, 1984: 40). In this context, knowledge of foreign languages is treated as skills directly linked to the societal needs the labor market responds to. Another link between LSP and the performativity imperative is the concept of life-long learning. As mentioned, one of the goals of certain LSP syllabi is to prepare learners for autonomous learning after course completion so they are able to incorporate developments in the domain discourse into their own linguistic capabilities. Viewed from a critical stance, life-long learning formats advocated currently illustrate the ever and fast developing expertise for which completing formal education in no way implies that the education itself is completed.

\section{Developing a more critical ESP stance}

Because it is bounded by the immediacy of its output, LSP pragmatism is perceived as "vulgar" by Cherryholmes (1988) and Pennycook (1997) who view it as an instrumental or functional view of language formed and influenced by social, cultural and political forces that shape the context of the professional word. In this sense, no language, LSP included, is neutral, but are all imbued with an understanding of the world or a worldview and, most often, ideology, "as always engaged in how we understand the world" (Pennycook, 1997: 258). The 'specificity' of LSP has raised acute concern with regard to the concept of power related and inherent to it. Critical perspective is called upon regarding each 'pillar' of such courses, most clearly articulated with respect to needs analysis. When defining needs analysis, it is esteemed, there should be greater awareness of wider societal and psychological implications regarding who sets the goals of LSP instruction, and why and how these are formulated, with a view to identifying whose interests they are embracing. Though LSP is, from the outset, acclaimed as a market-driven form of language teaching, and therefore presented as neutral, the rising critical approach sees its social goals as extending beyond the individual learner's ability to obtain employment, but rather as serving the profitoriented motives of global businesses and imperialistic political powers. In this perspective, LSP is viewed unconditionally as "accommodationist, assimilationist, colonizing" (Kumaravadivelu, 2006: 23). These arguments, focal for this consideration, reflect the pressing need to include the critical awareness of the insidious disempowering influence of such covert social forces upon learners in that, on account of the restrictive perspective of LSP, they are ultimately deprived of their professional and personal potential by being reduced to perpetuating capitalist ideology.

However, while these arguments of disempowerment are, to our mind, unconditionally real, they are not the exclusive interpretation and outcome of LSP instruction. It is a misleading oversimplification to present LSP as an educational support of existing ideological policies related to neoliberal capitalism. Constructive engagement with the criticism of LSP pragmatics is desirable in order to examine concerns to which it gives rise (Allison, 1996). LSP provides a linguistic 'arterial' network that allows for the fast 
and precise communication of new scientific findings or business solutions, thus crucially assisting in bringing tangible improvements to the society and lives of individuals. The advantages it brings are empowering both of a practicing individual and society since expertise without the adequate linguistic means of conveying it outside the immediate professional community makes it difficult to acquire not only the necessary professional/scientific practices, but also the many possible benefits of career upgrading, recognition, higher financial status, and overall personal satisfaction that leads to perceiving oneself as a fulfilled personality.

Critical views of LSP are far from being mainstream and there is a clear lack of LSP critical pedagogy (Belcher, 2006). With the emergence of English as a bridge language at the apex of the world language hierarchy (Ferguson, 2007: 9), the early years of ESP saw no interest in the broader social concerns around LSP, focusing essentially on its pragmatic value. The fact that critique is a relatively recent phenomenon in this area of study, that even today it remains a peripheral line of enquiry with regard to LSP theory and research, that it is largely ignored (if not resisted), indicates the absence of epistemological critical detachment and a systemic approach. Given that these constitute the keystones of research, LSP researchers need to widen their sphere of investigation to include the highly complex, contextual, social, and ideological aspects of professional language interactions.

There is a growing need to examine the possible ideological impact of expert discourses, with regard to unequal social distribution of professionally valued knowledge of literacies and genres, and of how they enable learners to gain a more prestigious social status (Hyland, 2000), and to look into how "language is the means of effecting or maintaining an unequal allocation of power and resources" (Phillipson, 1992: 55). Social constructionism, one of the most notable critical perspectives on ESP research centered upon rhetorical analyses of scientific discourse as advocated by Bazerman (1988), Myers (1990), and Swales (1990), criticizes the unsubstantiated stance towards 'neutrality' of professional discourses and claims that language, professional or not, is sustained by social processes.

\section{Critical awareness and pragmatism}

If such arguments are increasingly making LSP a contested field of research, they also contribute to strengthening its epistemological and practice framework. In line with the theory of symbolic power (Bourdieu, 1979), there is a growing understanding that pedagogical contexts are socially differentiated fields of practice and, consequently, that LSP needs a socio-theoretical orientation in order to first analyze and reveal the processes and aims of institutions that require LSP trained professionals. The beginning of theorizing an approach to the ethics of LSP practice, emanating from within the field itself, is perceived as a transition which goes far beyond subliminal servitude to the goals of contemporary business and ideological forces. Critical pragmatism entails constant evaluation of the socio-political conditions that shape educational policies and goals, and advocates favor of "epistemological, ethical, and aesthetic choices [...] and translating them into discourse-practices" (Cherryholmes, 1988, in Pennycook, 1997: 256).

A more critical approach with regard to LSP studies primarily calls for greater awareness of the socio-ideological and economic stakes involved in both research and 
teaching practice. Critical self-awareness regarding LSP practices can help achieve its stated educational aims within academia by engaging practice with corollary questioning regarding issues of power and ideology. Viewed in a critical perspective, LSP teaching needs to be less accommodationalist to overarching political and institutional orders, it needs to take into concern the sociodiscoursal, sociocultural, sociopolitical parameters, three primordial intersecting points of reference which go beyond mere concern with professional linguistic interactions in specific professional contexts. Researchers and practitioners are called upon to consider the wider social significance and implications of their work, and thus to conceive of themselves as having an obligation to "provide learners with ways of examining the academic sociopolitical status quo" (Hyland \& Hamp-Lyons, 2002: 9), in order to combat LSP being reduced to merely serving as a means of spreading a form of linguistic imperialism and empowering neoliberal capitalistic forces. Master warns against ESP if used to serve highly specified, "narrow" training that does not include wider "sociocultural domains whose specific purpose is not only access to and success in education or employment but also individual self-betterment" (1998: 78). In this perspective of restricting personal expression to a single segment of experience, LSP is opposed to the inherent nature of any language, i.e. an ontology of the entirety of human existence and its conceptualization. While, on the one hand, LSP undeniably serves goals of personal prosperity and professional stability, its insistence on ever increasing job performance, and on being ever more competitive in the global market economy, makes competition, rather than anything else, a defining characteristic of contemporary relations (Monboit, 2016).

When instructing learners in LSP, however demanding a syllabus and curriculum may be, there is always room to address issues regarding the very nature, essence, and ultimate purpose of learning this kind of language, leaving it up to learners to define their relation to the forces shaping their contemporaneity (Barton \& Hamilton, 1998). ESP/LSP lecturers can, within the boundaries and nature of their own domain, explain that any language is the reflection, the containment of human condition, that language use is always socially situated and indicative of broader social practice. This claim acknowledges the crucial relevance of this type of language instruction for the prosperity of a (global) society, and professionals individually, and that the really empowering LSP instruction is the one that includes developing learners' critical awareness of its own practices, thus directing them to articulate for themselves, unassisted, what their professional and personal stance will be, either one of mere unreflected performance, or one of enlightened contribution to the humanistic development of the society and their own personal fulfillment.

\section{BIBLIOGRAPHY}

Allison Desmond (1996), "Pragmatist Discourse and English for Academic Purposes", English for Specific Purposes, 15(2), 85-103. 
BALL Stephen (2003), "The Teacher's Soul and the Terrors of Perfomativity", Journal of Education Policy, 18(2), 215-28.

BARTON David \& HAMILTON Mary (1998), Local Literacies, London: Routledge.

BAZERMAN Charles (1988), Shaping Written Knowledge, Madison, WI: University of Wisconsin Press. BELCHER Diane (2006), "English for Specific Purposes: Teaching to Perceived Needs and Imagined Futures in Worlds of Work, Study, and Everyday Life", TESOL Quarterly, 40, 133-56.

BENESCH, Sarah (1993), “ESL, Ideology, and the Politics of Pragmatism”, TESOL Quarterly, 27, 70517.

BENESCH Sarah (2001), Critical English for Academic Purposes: Theory, Politics, and Practice, Mahwah, NJ: Lawrence Erlbaum.

BouRdiEu Pierre (1979), “Symbolic Power”, Critique of Anthropology, 4(13-14), 77-85.

Cherry holmes Cleo H. (1988), Power and Criticism: Poststructural Investigations in Education, New York: Teachers College Press.

Cherryholmes Cleo H. (1999), Reading Pragmatism, New York: Teachers College Press.

CROMBIE Winifred \& RIKA-HeKe Powhiri (1991), “ESP: Fact or Fiction?", Revista Alicantina de Estudios Ingleses, 4, 25-36.

CRYSTAL David (1997), English as a Global Language, Cambridge University Press.

FERGUSON Gibson (2007), “The Global Spread of English, Scientific Communication and ESP:

Questions of Equity, Access and Domain Loss", Ibérica, 13, 7-38.

HUCKIN Thomas (2003), “Specificity in LSP”, Ibérica, 5, 3-17.

HUTCHINSON Tom \& WATERS Alan (1987), English for Specific Purposes: A Learner-Centered Approach, Cambridge University Press.

HYLAND Ken (2000), Disciplinary Discourses: Social Interactions in Academic Writing, London: Longman. HYLAND Ken (2002), Teaching and Researching Writing, Pearson.

HYLAND Ken \& HAMP-Lyons Liz (2002), “EAP: Issues and Directions”, Journal of English for Academic Purposes, 1, 1-12.

KumARAVAdivelu Bala (2006), “Dangerous Liaison: Globalization, Empire and TESOL”, J. Edge (ed.), (Re-)Locating TESOL in an Age of Empire, Basingstoke: Palgrave Macmillan, 1-26.

LYOTARD Jean-François (1984), The Postmodern Condition: A Report on Knowledge, University of Minnesota Press.

MACKAY Ronald \& MOUNTFORd Alan (1978), English for Specific Purposes: A Case Study Approach, London: Longman.

MASTER Peter (1998), "Positive and Negative Aspects of the Dominance of English", TESOL Quarterly, 32, 716-27.

McDonough Jo (1984), ESP in Perspective: A Practical Guide, London and Glasgow: Collins ELT. MonBiot George (2016), "Neoliberalism - The Ideology at the Root of all Our Problems", The Guardian, <www.theguardian.com/books/2016/apr/15/neoliberalism-ideology-problemgeorge-monbiot> (accessed 28 September 2019). 
MORGAN Brian \& RAMANATHAN Vaidehi (2005), “Critical Literacies and Language Education: Global and Local Perspectives", Annual Review of Applied Linguistics, 25, 151-69.

MYERS Greg (1990), Writing Biology: Texts in the Social Construction of Scientific Knowledge, Madison, WI: University of Wisconsin Press.

PENNYCOOK Alastair (1994), The Cultural Politics of English as an International Language, London: Longman.

PENNYCOOK Alastair (1997), “Vulgar Pragmatism, Critical Pragmatism, and EAP”, English for Specific Purposes, 16, 253-69.

PenNYCoOK Alastair (2001), Critical Applied Linguistics, Mahwah, NJ: Lawrence Erlbaum.

PHILLIPSON Robert (1992), Linguistic Imperialism, Oxford: Oxford University Press.

StARfield Sue (2012), “Critical Perspectives on ESP”, B. Paltridge \& S. Starfield (eds), The Handbook of English for Specific Purposes, John Wiley \& Sons, 461-79.

STRONACH Ian \& MACLURE Margaret (1997), Educational Research Undone: The Postmodern Embrace, Buckingham: Oxford University Press.

SWALES John (1985), Episodes in ESP, Oxford: Pergamon Press.

SWALES John (1990), Genre Analysis: English in Academic and Research Settings, Cambridge: Cambridge University Press.

SWALES John \& FEAK Christine (2004), Academic Writing for Graduate Students: Essential Tasks and Skills (2nd edition), Ann Arbor: University of Michigan Press.

WIDDowson Henry (2003), Defining Issues in English Language Teaching, Oxford: Oxford University Press.

\section{ABSTRACTS}

In its inception and consequent development, English for Specific Purposes implied precise modeling of language instruction to prepare professionals for the global job market. The language skills imparted are designed to make them competitive in terms of obtaining and maintaining professional posts and, in certain cases, to equip them to follow the future language developments required to retain the post. Mastering domain lexicon, rhetoric, and stylistics, undeniably empowers ESP learners' career advancement potential. However, in view of such narrowly defined axial purposes, ESP has been referred to as a "restricted" language (Mackay \& Mountford, 1978), which excludes other aspects of human experience, and is therefore also 'restrictive'. As such, it does not involve any ontology, profound layers or nuances of human attempts to comprehend the entirety of existence, but rather "performativity" which Lyotard (1984) criticized as the imperative of neoliberal capitalism which sees competition as the defining characteristic of human relations, a process that rewards merit and punishes inefficiency (Monboit, 2016). In spite of this, this paper argues that LSP can be an indispensable tool for social and personal advancement on the condition that LSP learners are empowered with unbiased critical awareness towards their desired professional environment so as to autonomously discern their own position in it, whether by simply adding to the further enhancement of the existing "performative" neoliberal capitalistic setting, or by making a difference by humanizing it, and striving towards a more complete personal existence. 
Depuis son apparition, l'évolution d'English for Specific Purposes (ESP) s'est fondée sur une approche spécifique de l'enseignement de la langue visant à préparer les novices et les professionnels pour le marché du travail mondialisé. Les compétences langagières enseignées ont pour objectif d'accroitre la performance de ces apprenants et de les aider à renforcer leur capacité à obtenir et garder cet emploi et, dans certains cas, à suivre les évolutions langagières requises afin de conserver leur emploi. Maitriser les aspects lexicaux, rhétoriques et stylistiques propres au domaine aide indéniablement les apprenants de l'ESP dans leur évolution de carrière. Cependant, en raison de ces objectifs limités, certains chercheurs ont qualifié l'ESP de langue « restreinte» (Mackay \& Mountford, 1978), qui exclut d'autres volets de l'expérience humaine et s'en trouve donc également être « restrictive ». En tant que tel, l'ESP n'implique aucune réflexion ontologique, ni fondement profond, ni nuance des tentatives visant à rendre compte de l'existence dans sa complexité, mais relève plutôt de la «performativité », que Lyotard (1984) a critiqué en tant qu'impératif du capitalisme néolibéral qui envisage la concurrence comme définitoire des relations humaines, et que Monboit (2016) considère comme un processus qui récompense le mérite et sanctionne l'inefficacité. Malgré ces critiques fortes, cet article tente de montrer que l'ESP peut se révéler également un outil indispensable pour le développement à la fois social et personnel des apprenants, à la condition que ces derniers soient formés à porter un regard conscient, impartial et critique sur leurs objectifs langagiers et sur le contexte professionnel, pour leur permettre d'y analyser leur propre position de façon autonome, soit en participant au développement du contexte capitaliste néolibéral "performatif ", soit en les amenant à introduire une approche différente, plus humaine, et à se battre pour la réalisation pleine de leur propre condition.

\section{INDEX}

Mots-clés: anglais de spécialité, langue restreinte, « performativité », capitalisme néolibéral, distance critique

Keywords: English for Specific Purposes, restricted language, performativity, neoliberal capitalism, critical stance

\section{AUTHOR}

\section{NADEŽDA STOJKOVIĆ}

University of Niš (Serbia).

Dr. Nadežda Stojković is Associate Professor of ESAP, University of Niš, Serbia, and visiting professor of LSP Theory, Mykolas Romeris University, Vilnius, Lithuania.

She is founding editor and editor-in-chief of The Journal of Teaching English for Specific and Academic Purposes. She has published four ESAP textbooks and is editor of three ESP monographs for Cambridge Scholars Publishing, UK, and two for Vernon Press, Spain/USA.

nadezda.stojkovic@elfak.ni.ac.rs 